\title{
The effects of chronic ethanol challenges on aggressive responding in rats maintained on a semideprivation diet
}

\author{
JAMES L. TRAMILL \\ Wichita State University, Wichita, Kansas 67208 \\ ANDREA L. WESLEY \\ University of Southern Mississippi, Hattiesburg, Mississippi 39401 \\ and \\ STEPHEN F. DAVIS \\ Emporia State University, Emporia, Kansas 66801
}

\begin{abstract}
A 2 by 3 factorial design was used to evaluate the effects of type of injection (saline vs. ethanol) and amount injected $(.25 \mathrm{cc}, .50 \mathrm{cc}, .75 \mathrm{cc} / 100 \mathrm{~g}$ body weight) on shock-elicited aggression. All subjects were maintained on a restricted diet for the duration of the experiment. Intraperitoneal injections were administered to all subjects each day for 15 days. On the 15th day, each subject received shock-elicited aggression testing $15 \mathrm{~min}$ after the daily injection. The results indicated that the alcohol-injection subjects were significantly more aggressive than were the saline-injected subjects at the .25-cc level, but these subjects were significantly less aggressive at the .75-cc level.
\end{abstract}

Reported findings concerning the effects of alcohol (ethanol) on aggression in animals have tended to be inconsistent. Inhibition of aggressive responding as a function of ethanol challenges has been reported in domestic cocks (Kovach, 1967), white mice (Bertilson, Mead, Morgret, \& Dengerink, 1977), and white rats (Tramill, Turner, Sisemore, \& Davis, 1980). Increased rates of aggressive responding following ethanol challenges have been reported in Siamese fighting fish (Raynes \& Ryback, 1970) and white rats (Weitz, 1974). As these different investigations have employed a variety of animal subjects, one might argue that the inconsistencies are due to a species-specific differential response to alcoholic challenges. As, however, the Tramill et al. (1980) and Weitz (1974) studies both employed white rats as subjects, one is forced to look further for an adequate explanation.

While the Tramill et al. (1980) and Weitz (1974) studies both employed a shock-elicited aggression situation and utilized similar injection dosage levels, there were important methodological differences. Tramill et al. (1980) employed a single acute challenge of alcohol prior to aggression testing in the singlerestrained animal situation, whereas Weitz (1974) utilized a repeated-measures design in the paired-animal situation. Thus, the Weitz (1974) study was, in effect, a chronic injection condition. As Wesley and Tramill (Note 1) have reported a drop in food consumption in

Requests for reprints should be directed to James L. Tramill, Department of Instruction Services, Wichita State University, Wichita, Kansas 67208. animals exposed to chronic ethanol injections, the results reported by Weitz may have been, at least to some extent, influenced by food restriction (see Cahoon, Crosby, Herrin, Hill, \& McGinnis, 1971) or an interaction between food deprivation and alcohol injection. The present study was designed to investigate the effects of chronic ethanol challenges on aggressive responding in animals maintained on a controlled diet.

\section{METHOD}

\section{Subjects}

Forty-two male albino rats obtained from the Holtzman Company, Madison, Wisconsin, served as subjects. The animals were approximately 180 days old at the time of testing. All subjects were individually housed, with food and water freely available prior to the beginning of the experiment. For the 15-day experimental period, all animals were maintained on a $12-\mathrm{g} /$ day diet.

\begin{abstract}
Apparatus
Testing took place in a shock-elicited aggression apparatus (more fully described in Tramill et al., 1980) consisting of an opaque restraint tube, shock source (BRS/LVE shock generator, SG-905), target rod (Lafayette, Model 80111, omnidirectional lever), and impulse counter (Lafayette, Model 5707PS). Attack upon the target rod, which extended across the midportion of the open end of the restraint tube, activated the impulse counter, thus yielding an automated record of the number of responses made by each subject. The subject's tail was extended through a $1.50-\mathrm{cm}$ hole in the closed end of the restraint tube. Once a subject was in place in the restraint tube, a wooden dowel rod was secured to the tail by means of adhesive tape, thus prohibiting escape during shock testing. Two copper wires, permanently attached to the dowel rod $7.00 \mathrm{~cm}$ apart, served as electrodes for the administration of tailshock.
\end{abstract}




\section{Procedure}

At the begiuning of the experiment, the subjects were randomly distributed across six equal groups $(n=7)$ and placed on a restricted diet of $12 \mathrm{~g}$ of lab chow per day. Subjects in the alcohol (A) condition (Groups A-25, A-50, and A-75) received intraperitoneal injections of one of three doses of a solution of $30 \%$ ethanol $(\mathrm{v} / \mathrm{v})$ in isotonic saline each day for 15 days. Subjects in the saline (S) condition (Groups S-25, S-50, and S-75) received one of three doses of an isotonic saline solution each day for 15 days. The experimental treatments were .25 , .50 , and $.75 \mathrm{cc}$ of solution per $100 \mathrm{~g}$ of body weight (adjusted daily). The behavioral effects of these doses of ethanol on rats have been previously determined (Buckalew \& Cartwright, 1968) and provide consistency with the Weitz (1974) report. The last day of injection for these groups was also the day of shock testing.

On the day of testing, each subject was individually tested $15 \mathrm{~min}$ after receiving the appropriate intraperitoneal injection. Following a 5-min habituation period, each subject received a 10 -min period of tailshock administration. During this time, $1.50-\mathrm{mA}$ shocks of $300 \mathrm{msec}$ duration were administered at $3-\mathrm{sec}$ intervals. Thus, each subject received a total of 200 shocks. The order for running subjects was randomized. The number of aggressive responses was recorded for each animal.

\section{RESULTS AND DISCUSSION}

Prior to analysis, the response data were converted to $\log _{10}\left(X_{i}+1\right)$ scores. Group mean responses are shown in Figure 1. Analysis of variance, incorporating type of injection (saline vs. alcohol) and amount injected $(.25 \mathrm{cc} / 100 \mathrm{~g}, .50 \mathrm{cc} / 100 \mathrm{~g}$, and $.75 \mathrm{cc} / 100 \mathrm{~g})$ factors, yielded significance for the amount injected $[F(2,36)=$ $8.17, \mathrm{p}<.01]$ and the type of injection by amount injected interaction $[F(2,36)=7.69, p<.01]$. Simple main effect analyses, used to probe the significant interaction, indicated that saline-injected subjects and alcohol-injected subjects differed significantly at the $.25-\mathrm{cc}[\mathrm{F}(1,36)=10.75, \mathrm{p}<.01]$ and $.75-\mathrm{cc}[\mathrm{F}(1,36)=$ $4.85, \mathrm{p}<.05$ ] levels and that a significant difference $[F(2,36)=15.85, p<.01]$ existed between the .25 -, $.50-$, and $.75-\mathrm{cc}$ levels under the alcohol-injection condition. The Newman-Keuls procedure was used to test for specific injection-amount differences under the alcohol condition. It was found that both the $.50-\mathrm{cc}$ and $.25-\mathrm{cc}$ conditions produced significantly $(p<.01)$ higher aggression scores than did the .75 -cc condition. Additionally, the .25-cc condition produced significantly $(p=.05)$ more aggressive responses than did the .50 -cc condition.

The results of the present study suggest that chronic injections of a $30 \%$ ethanol solution at low $(.25 \mathrm{cc} / 100 \mathrm{~g})$ and moderate $(.50 \mathrm{cc} / 100 \mathrm{~g})$ dose levels tend to increase aggressive responding in rats maintained on a restricted food-intake diet. The results of the high dose level $(.75-\mathrm{cc} / 100 \mathrm{~g})$ treatment appears to be one of inhibition, possibly due to debilitation. These results closely parallel those reported by Weitz (1974) and give support to the notion of an interactive effect of food-intake restriction and chronic ethanol challenges leading to increased

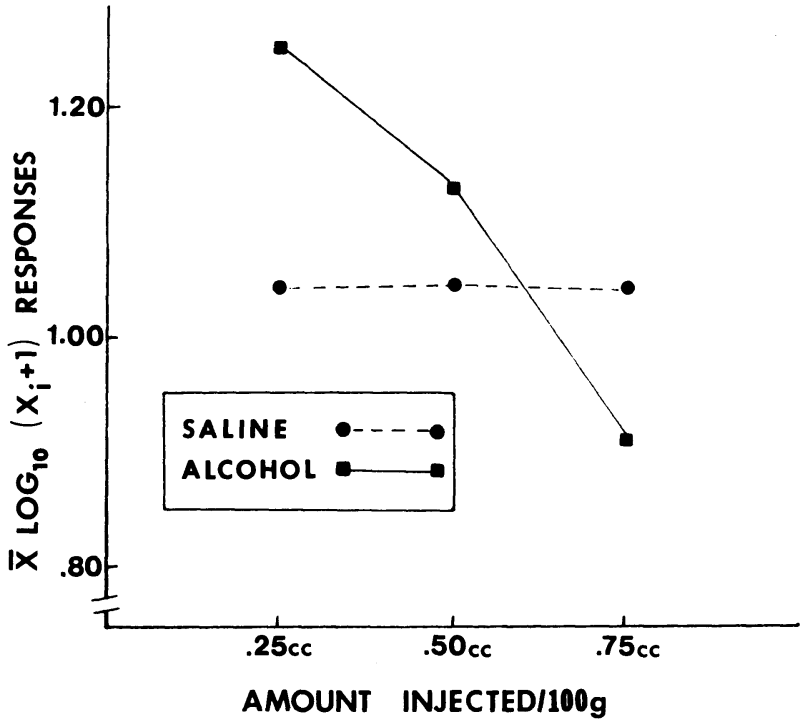

Figure 1. Mean aggressive responses during shockelicited aggression training.

aggressive responding. However, before such conclusions can be drawn, additional research is needed to directly compare the effects of acute vs. chronic ethanol challenges, as well as various states of food restriction.

\section{REFERENCE NOTE}

1. Wesley, A. L., \& Tramill, J. L. Aggressive responses to chronic injections of ethanol reflect a dose-dependent relationship. Paper presented at the 26th annual meeting of the Southwestern Psychological Association, Oklahoma City, 1980.

\section{REFERENCES}

Bertilson, M. S., Mead, J. D., Morgret, M. K., \& Dengerink, H. A. Measurement of mouse squeals for 23 hours as evidence of long term effects of alcohol on aggression in pairs of mice. Psychological Reports, 1977, 41, 247-250.

Buckalew, L. W., \& Cartwright, G. M. General and differential behavioral effects of five ethanol dosages on the albino rat. Psychological Reports, 1968, 23, 1151-1154.

Cahoon, D. D., Crosby, R. M., Dunn, S., Herrin, M. S., Hill, C. C., \& McGinsis, M. The effect of food deprivation on shock-elicited aggression in rats. Psychonomic Science, 1971, 22, 43-44.

Kovach, J. K. Maternal behavior in the domestic cock under the influence of alcohol. Science, 1967, 156, 835-837.

RAYNes, A. E., \& RYBACK, R. S. Effects of alcohol and congeners on aggressive response in Beta splendens. Quarterly Journal of Studies on Alcohol, 1970, 5, 130-133.

Tramill, J. L., Turner, P. E., Sisemore, D. A., \& Davis, S. F. Hungry, drunk, and not real mad: The effects of alcohol injections on aggressive responding. Bulletin of the Psychonomic Society, 1980, 15, 339-341.

Weitz, M. K. Effects of ethanol on shock-elicited fighting behavior in rats. Quarterly Journal of Studies on Alcohol, $1974,35,953-958$.

(Received for publication December 4, 1980.) 